\title{
Akademik Gelişim Ve Finansal Okuryazarlık Arasındaki İlişkinin Tespiti Üzerine Bir Araştırma
}

\author{
Sedat DURMUŞKAYA*
}

\author{
Yusuf Bahadır KAVAS ${ }^{* *}$
}

\begin{abstract}
$\ddot{O} Z$
Finansal okuryazarlik finansal piyasaları anlayabilme, tasarruf ve tüketim dengesini kurabilme, finansal risk ve çeşitli alternatifler arasından doğru seçimleri yapabilme yeteneği olarak tanımlanabilir. Finansal okuryazarlık; bireylerin kredi kartı kullanımı, emeklilik planları, konut ve bireysel kredi kullanımının hangi zamanlarda avantajlı olduğunu, sigorta gibi faaliyetlerin nasıl işlediğini ve hangilerinin bireylerin çıkarlarına hizmet ettiğini ortaya çıkarır. Kişilerin finansal okuryazarlık düzeyinin yüksek olmast finansal piyasaları anlamalarına ve risk-getiri dengesi kurmalarına yardımcı olur. Özellikle üniversite gençliğinin finansal okuryazarlık düzeyinin yüksek olması ülke geleceğini şekillendirmek için gereklidir. Üniversiteye gelmiş bireylerin finansal okuryazarlık düzeylerini artırmak sadece finans derslerine giren akademisyenlerle mümkün değildir. Bu kültürü kazandırmak ancak üniversitedeki akademisyenlerin tamamının temel finans bilgilerinin yükseltilmesi ile gerçekleştirilebilecektir. Çalışmamızda Türkiye'deki akademisyenlerin finansal okuryazarlık düzeylerini ölçmek amacıyla temel ve gelişmiş finansal okuryazarlık düzeylerini ölçen sorular sorulmuştur. Anket dört yüz on beş akademisyene uygulanmiştır. Bu kapsamda erkek akademisyenlerin kadınlardan, sosyal bilimler alanında çalışan akademisyenlerin sağllk bilimlerinde çalı̧̧anlardan, lisansüstü mezunu olan akademisyenlerin lisans mezunu olanlardan, ögretim görevlisi ve öğretim üyesi olan akademisyenlerin araştırma görevlisi olanlardan finansal açıdan daha okuryazar olduğu sonucuna ulaşılmıştır. Ayrıca akademisyenlerin yaşları arttıkça finansal okuryazarlı düzeylerinin artmakta olduğu tespit edilmişstir.
\end{abstract}

Anahtar Kelimeler: Finansal okuryazarlik, Finansal bilgi

Jel Siniflandirmast: G40,G41

\section{A Research on the Determination of the Relationship Between Academic Improvement and Financial Literacy}

\begin{abstract}
Financial literacy can be defined as the ability of financial markets to understand, to set the savings and consumption balance, financial risk and to make the right choice among various alternatives. Financial literacy; reveals individuals use credit cards, retirement plans, when it is advantageous to use housing and personal lending, how work activities such as insurance, and which ones serve their interests. The high level of financial literacy of people helps to understand financial markets and establish a risk-return balance. In particular, the high level of financial literacy of university youth is necessary to shape the country's future. Increasing the financial literacy of individuals who have come to the university is not possible with the only academicians who are in finance courses. Gaining this culture can be achieved by upgrading the basic financial information of all academics in universities.In this research; In order to measure the financial literacy levels of academicians who are working in Turkey, questions were asked about basic and advanced financial literacy levels. Four hundred and fifteen academics were employed in the
\end{abstract}

\footnotetext{
* Dr. Öğr. Üyesi, Sakarya Uygulamalı Bilimler Üniversitesi, Karasu M.Y.O. Muhasebe ve Vergi Bölümü, sdurmuskaya@sakarya.edu.tr

** Öğr. Gör., Bilecik Şeyh Edebali Üniversitesi, Osmaneli M.Y.O. Muhasebe ve Vergi Bölümü, Yusuf.kavas@ bilecik.edu.tr
} 
survey. Consequently, by the meaning of financial literacy level male academicians, academicians which are studying on social sciences, academicians whose have post graduate degree and faculty members are higher than female acedemicians, academicians on health sciences, academicians whose have graduate degree and lecturers respectively. In addition, as the age of academicians increases, financial literacy levels also increase.

Keywords: Financial literacy, Financial information

Jel Classification: $G 40, G 41$

\section{GíRiş}

Finansal okuryazarlık finansal piyasaları anlayabilme, tasarruf ve tüketim dengesini kurabilme, finansal risk ve çeşitli alternatifler arasından doğru seçimleri yapabilme yeteneği olarak tanımlanabilir. Finansal okuryazarlık bireylere kredi kartı kullanımı, emeklilik planları, konut ve bireysel kredi kullanımının hangi zamanlarda avantajlı olduğu, sigorta gibi faaliyetlerin nasıl işlediği ve hangilerinin bireylerin çıkarlarına hizmet ettiğini ortaya çıkarır. Kişilerin finansal okuryazarlık düzeyinin yüksek olması finansal piyasaları anlamalarına ve riskgetiri dengesi kurmalarına yardımcı olur. Özellikle üniversite gençliğinin finansal okuryazarlık düzeyinin yüksek olması ülke geleceğini şekillendirmek için gereklidir. Üniversiteye gelmiş bireylerin finansal okuryazarlık düzeylerini artırmak sadece finans derslerine giren hocalarla mümkün değildir. Bu kültürü kazandırmak ancak üniversitedeki akademisyenlerin tamamının temel finans bilgilerinin yükseltilmesi ile gerçekleştirilebilecektir.

Literatürde finansal okuryazarlık kavramı temel ve gelişmiş finansal okuryazarlık olarak ikiye ayrılır. Faiz oranlarını anlayabilme, enflasyonun etkilerini kavrayabilme ve risk çeşitliliğini algılama temel finansal okuryazarlık düzeyi olarak kabul edilirken; bono fiyatları, faiz oran hesaplamaları ve hisse senedi piyasası gelişmiş finansal okuryazarlık düzeyi olarak değerlendirilir.

Finansal okuryazar olabilmek için geniş çapta finansal bilgiyi araştırma ve toplama yeteneğinizin olması gerekir. Daha sonra elde edilen bu bilgilere eleştirel gözle bakıp içlerinden sizin için faydalı olanları seçebilirseniz finansal okuryazarlık becerisine sahipsiniz demektir.

Dünya genelinde finansal okuryazarlık düzeyinin ölçülmesi ile ilgili en geniş çapta çalışma FINLIT (Financial Literacy) tarafindan 148 ülkede 150.000 'den fazla yetişkine 2015 yılında yapılmıştır. Anket soruları genel olarak risk çeşitliliği, enflasyon, basit faiz-bileşik faiz hesaplamaları ve kredi kullanımı başlıklarında şekillendirilmiştir. Bu çalışma sonuçlarına göre Dünya çapındaki yetişkinlerin yaklaşık 3 'te 1 'i finansal kavramları anlayabilmişler, erkeklerin finansal okuryazarlık düzeyi yüzde 35 , kadınlarınki ise yüzde 30 civarında çıkmıştır. Aynı çalışmada yüksek gelir seviyesine sahip olan kişilerin finansal bilgilerinin daha iyi çıktığı görülmüştür. Yine çalışmada kişilerin eğitim seviyeleri yükseldikçe finansal okuryazarlık düzeylerinin de buna paralellik gösterdiği ortaya çıkmıştır.

Finansal okuryazarlığın artırılması hem finansal piyasaların etkinliğini artıracak hem de toplumun kredilere, bireysel emekliliğe, faiz oranlarına, temel ekonomik göstergelere ve tasarrufa olan bakış açısını değiştirecektir. 
Finansal hizmetleri (mobil bankacılık, kredi kartı vb.) kullanmak finansal piyasaları anlamak açısından önemlidir. Finansal piyasaları anladıkça finansal okuryazarlık artırılabilecek bu sayede ileride ulusal, bölgesel ya da küresel krizler nedeniyle oluşabilecek olumsuz durumlara karşı bireylerin hazırlıklı olması sağlanabilecektir. Toplumdaki bireylerin böyle durumlarla karşılaşmamak için gerekli hassasiyeti göstermelerinin önü açılacaktır. Bu açıdan finansal hizmetler ve finansal okuryazarlık bağlantısı doğrudan birbiriyle ilişkilidir.

Bireyler çeşitli finansman araçlarını kullanarak birikimlerini yatırıma dönüştürürler. Bunun sonucunda gelir elde etmeyi hedeflerler. Finansal okuryazarlık hane halkının daha fazla tasarruf yapma eğilimini artıracaktır. Çünkü finansal okuryazarlık sayesinde daha doğru yatırımlar yapılarak risk-getiri dengesi iyi kurulup daha yüksek gelir elde edeceğini kişi artık bilecektir. Tasarrufların artması ve neticesinde finansal piyasalarda değerlenmesi fon ihtiyacı duyan şirketlere gerekli fonu sağlayacak ve yatırıma dönüşecektir. Bu durum ülke ekonomisinin büyümesi ve gelişmesi açısından da çok önemlidir.

Finansal okuryazarlığın bir başka toplumsal önemi; kişilerin yanlış kararları neticesinde oluşabilecek iflas ya da haciz gibi durumları en aza indirmesidir. $\mathrm{Bu}$ şekilde ekonomik sorunlardan dolayı ortaya çıkan toplumu olumsuz etkileyen boşanmaların sayısında da azalma görülebilecektir.

Ülkemizdeki akademisyenlerin gelir seviyesi ülke ortalamasının üzerindedir. Finansal okuryazarlığın da beraberinde yüksek çıkması beklenilecek bir durumdur. Çalışmada akademisyenlerin farklı demografik özellikleri ile temel finans bilgileri, bireysel emeklilik uygulaması, trafik sigorta hizmetleri, ülkenin içinde bulunduğu ekonomik durum, yatırım bilgileri ve bankacılık sistemi hakkında karşılaştırmalar yapılıp sonuçlar elde edilecektir.

\section{I.LITERATÜR}

Lusardi ve Mitchell (2014) tarafından yapılan araştırmaya göre Dünya üzerinde kadınların yüzde 30 'u erkeklerin ise yüzde $35^{\prime}$ 'i finansal okuryazardır. Kadınların finansal bilgileri, gelir, eğitim, ülke, yaş varyasyonları düşünüldüğünde bile erkeklerinkinden daha düşüktür.

Barış (2016) tarafından finansal okuryazarlık ve bütçe davranışı ile ilgili üniversite öğrencileri üzerine yapılan bir çalışmada finansal okuryazarlık düzeyi ile kişinin bütçeleme davranışları arasında anlamlı bir farklılığın olmadığı ve üniversite ögrencilerinin temel finansal bilgilerinin yeterli ancak ileri finansal bilgilerinin düşük olduğu tespit edilmiştir. Çalışma sonuçlarına göre dünya genelinin aksine kız öğrencilerin finansal okuryazarlığı erkek öğrencilerinkinden yüksek çıkmıştır.

Kılıç, Ata ve Seyrek' in (2015) finansal okuryazarlık üzerine üniversite öğrencilerine yaptıkları çalışmada öğrencilerin finansal okuryazarlık düzeyi genel olarak yüzde 48 çıkmıştır. FINLIT'in 2015 yılında yaptı̆̆ Türkiye'deki yetişkinlerin finansal okuryazarlık düzeyi yüzde 24 çıkmıştır. Üniversite öğrencileri ve Türkiye ortalaması karşılaştırıldığında üniversite öğrencilerinin finansal okuryazarlık düzeyinin yüksek çıktı̆̆1 görülmektedir. Yapılan çalışmada kredi kartı kullanımı ile internet bankacılı̆̆ kullanımının 
finansal okuryazarlık düzeyinde farklılık ortaya koyduğu görülmüştür. Ayrıca erkeklerin finansal okuryazarlığı kadınlarınkinden daha yüksek çıkmış ve Öğrencilerin de; bankacılık bilgilerinin iyi, yatırım bilgilerinin ise yetersiz olduğu görülmüştür.

Biçer ve Altan'1n (2016) üniversite öğrencilerinin finansal okuryazarlık düzeylerini ölçmek için yaptıkları çalışmada öğrencilerin harcama, tutum, alg1 ve ilgileri ile alakalı 4 boyutta finansal bilgileri incelenmiştir. İnceleme yapılan bu alanlarla ilgili olarak, finansal bilgi ile cinsiyet arasında farklılık tespit edilmemiştir. Finansal eğitim alan kişilerin finansal algılarının daha yüksek olduğu ve üniversite öğrencilerinin sınıfları arttıkça ilgi ve algılarının arttığı görülmüştür.

Şamiloğlu, Kahraman ve Bağcı (2016) tarafindan Erciyes Üniversitesi öğrencilerine yapılan uygulamada işletme öğrencilerinin diğer bölüm öğrencilerinden, erkek öğrencilerin de kadın öğrencilerden daha iyi finansal okuryazarlık düzeyine sahip olduğu tespit edilmiştir.

Er, Şahin ve Mutlu (2017) tarafından finansal okuryazarlık ve finansal eylemle ilgili üniversite öğrencileri üzerine yapılan çalışmada öğrencilerin genel finansal okuryazarlık düzeylerinin düşük olduğu, kredi kartı kullanımı, mali yardım alımı ve finansal bilgi düzeyi ile finansal okuryazarlık arasında anlamlı bir farklılığın olmadığı tespit edilmiştir.

Gutnu ve Cihangir (2015) tarafindan Osmaniye'deki Korkut Ata Üniversitesi'nde çalışan personelin finansal okuryazarlık düzeyiyle ilgili yapılan çalışmada üniversite personelinin yüzde 84'ünün Dünyada ve Türkiye'deki finansal gelişmeleri genellikle takip ettiği, yüzde $25^{\prime}$ 'inin ise her gün takip ettiğ görülmüştür. Çalışmaya katılan kişilerin yüzde 48'i ise gazetelerdeki finans ve ekonomi haberlerini okuduklarını belirtmişlerdir. Katılımcıların yüzde 86'sı internet bankacılığını kullanmakta olduğu ve yüzde 60'ının ise kredi kartı aylık faiz oranlarını bildiği tespit edilmiştir.

Danışman, Sezer ve Gümüş (2016) tarafindan üniversite öğrencileri üzerine yapılan çalışmada öğrencilerin temel düzeydeki finansal bilgilerini ölçen soruları doğru cevaplandırdıkları ancak ileri düzey finansal bilgilerinin düşük olduğu görülmüştür. Öğrencilerin kaçıncı sınıfta oldukları ile temel faiz bilgisi arasında ve bunun yanında öğrenim görülen bölüm ile paranın yönetimi arasında anlamlı ilișki olduğu tespit edilmiştir.

Lusardi, Mitchell ve Curto'nun (2010) gençler üzerine yaptıkları çalışmada gençlerin finansal okuryazarlık düzeylerinin düşük olduğu, genç yetişkinlerin 3'te 1'inden daha azının faiz oranları, enflasyon ve risk çeşitliliği hakkında bilgisinin olduğu, aynı zamanda finansal okuryazarlığın ailenin finansal durumu ve sosyo demografik faktörleri ile bağlantılı olduğu bulunmuştur. Özellikle ailesinin emeklilik birikimi olan ve kolej eğitimi almış bir erkekle, ailesi zengin olmayan ve lise eğitiminden daha az bir eğitime sahip kadın risk çeşitliliğ konusunda karşılaştırıldığında erkeğin bilgisinin yüzde 45 daha fazla olduğu ortaya çıkmıştır. 
Huston (2010) tarafindan yapılan çalışmada son 10 yılda finansal okuryazarlık konusunda yapılmış çalışmalar özetlenmiş ve finansal okuryazarlığın ölçümünün standartlaştırılması noktasına vurgu yapmıştır.

Japelli ve Padula (2013) yaptıkları çalışmada kişilerin matematiksel yeteneklerinin gelecekte elde edecekleri finansal okuryazarlığ potansiyel bir rolünün olduğunu savunmuşlardır. Sosyal güvenlik sistemleri daha cömert olan ülkelerin finansal okuryazarlık düzeylerinin düşük olduğunu bulmuşlardır. Finansal piyasaların bireysel emeklilik fonları gibi yatırım araçları ile çeşitlendirilip reformların yapılması neticesinde yüksek finansal okuryazarlığa ve tasarrufa yol açtığı bilgisine ulaşmışlardır.

Almenberg ve Söderbergh (2011) finansal okuryazarlık ve emeklilik planlaması arasındaki ilişsiyi İsveçli yetişkinlere temsili örneklem ile incelemişler ve finansal okuryazarlık düzeyinin kadınlar, yaşl1lar, eğitim seviyesi düşük olanlar ve geliri az olanlarda düşük çıtığını ortaya koymuşlardır.

Dıck ve Jaroszek (2013) Almanya'daki tüketici kredisi kullanımın belirleyicilerini araştırdıkları çalışmalarında kolay erişilebilen ancak nispeten daha pahalı olan tüketici kredisi sıklığının finansal okuryazarlıkla ters ilişki içinde olduğunu ortaya koymuşlardır. Ayrıca finansal eğitimin tüketici tercihlerini iyileştirmek için önemli bir rol oynadığını belirtmişlerdir.

Mahdzan ve Tabiani (2013) Malezya özelinde finansal okuryazarlığın tasarruf üzerindeki etkisini incelemişlerdir. Çalışmanın bulguları finansal okuryazarlık düzeyinin bireysel tasarruf üzerinde önemli ve olumlu bir etkisi olduğunu göstermektedir. Düzenli birikimin, cinsiyetin, gelir ve eğitim düzeyinin korunmasının tasarruf etme olasılığını olumlu yönde etkilediği sonucuna ulaşılmıştır.

Amagir, Groot,Brink vd. (2017) çocuklar ve ergenler için finansal okuryazarlık eğitim programlarının gözden geçirilmesiyle alakalı çalışmada finansal okuryazarlık eğitim programlarının çocuklardaki ve ergenlerdeki etkinliğini değerlendirmişlerdir. Ayrıca başarılı bir finans eğitim müfredatının temel özelliklerini tanımlanmışlardır. Çalışmada okul temelli finansal eğitim programlarının çocukların ve ergenlerin finansal bilgi ve tutumlarını geliştirdiği saptanmıştır. İlköğretim düzeyindeki ve ergenlik dönemindeki çocuklara finansal bilgiyi en iyi öğretme metodu olarak deneyimsel öğrenme gösterilmiştir.

Solomon,Nhete,Sithole (2018) çalışmalarında 21. yy daki öğrencilerin finansal okuryazarlık düzeyinin hem gelişmiş hem de gelişmekte olan ülkelerde çok düşük olmasından dolayı bu durumun halkların refahı üzerinde olumsuz etkisi olduğunu vurgulamışlardır. Çalışmada Botswana ülkesinde ortaokul düzeyindeki müfredat incelenmiştir. İnceleme sonucunda öğrencilere kişisel finansal okuryazarlık sunmanın gerekliliği tespit edilmiştir. Halihazırdaki mevcut müfredat ve iş alanları ihtiyacı karşılayamadığı için müfredata zorunlu olarak bu konunun konulması gerektiği anlatılmıştır.

Yıldırım, Bayram, Oğuz vd. (2017) tarafından yapılan kişilerin finansal okuryazarlık düzeyleri ve demografik değişkenlerle ilişkisini ölçtükleri çalışmaya Karabük'te demir çelik sektöründe çalışan 304 kişi katılmıştır. Araştırmaya 
katılanların yüzde 8,9 'u temel finansal okuryazarlık sorularını doğru cevaplamışlardır. Eğitim ve aylık gelirin finansal okuryazarlık konusunda anlamlı ve önemli belirleyici olduğu tespit edilmiştir.

Ricci, Caratelli (2017) finansal okuryazarlık, emeklilik planlaması ve finansal kurumlara duyulan güven arasındaki ilişkiyi 2010 y1lında İtalya hane halkı üzerine yaptıkları anket çalışması ile incelemişlerdir. Bulunan sonuçlara göre güvenin hem bireysel emeklilik kararlarında hem de kıdem tazminatını özel emeklilik sistemine ayırma üzerinde olumlu bir etkiye sahip olduğu tespit edilmiştir.

\section{ARAŞTIRMANIN YÖNTEMI}

$\mathrm{Bu}$ çalışma ile eğitim seviyesi ve gelir seviyesi ile ülke ortalamasının üzerinde olan akademisyenlerin finansal okuryazarlık düzeylerinin ölçülmesi hedeflenmiştir. $\mathrm{Bu}$ kapsamda tamamı Marmara Bölgesi'nde olan çeşitli üniversitelerin akademik personellerine doğrudan e-posta gönderilerek anketin cevaplandırılması sağlanmıştır. 2018 yılı Şubat ve Mart aylarında toplamda kolayda örneklem kapsamında 3200 kişiye e-posta gönderilmiş, doldurulan 415 anket üzerinde analizler yapılmıştır. Kişilerin temel finans bilgilerini ve gelişmiş finans bilgilerini ölçen 25 soru sorularak finansal okuryazarlık düzeyleri tespit edilmeye çalışılmıştır. Sorular genel olarak (Türkiye'deki Ekonomik Durum, Bireysel Emeklilik ve SGK' dan Emeklilik, Bankacılık Sistemi, Trafik Sigortası ve Kaskosu, Yatırım Bilgileri, Türk Vergi Sistemi) konuları üzerinde yoğunlaştırılmıştır. Anketler SPSS programı ile çözümlenmiş, ANOVA T testi ile demografik değişkenlerle finansal okuryazarlık düzeylerini ölçen sorulara verilen cevaplar arasında anlamlı bir fark olup olmadığ test edilmiştir.

\section{BULGULAR}

$\mathrm{Bu}$ çalışmada Marmara Bölgesinde yer alan üniversitelerdeki akademisyenlerin finansal okuryazarlık düzeyleri araştırılmıştır. Yapılan anket çalışmasında demografik özellikler (Yaş,Cinsiyet, Eğitim Durumu, Akademik Unvan, Gelir Durumu, Çalışma Alanı, Bireysel Emekliliğe Dahil Olup Olmaması, Kredi Kartı ve İnternet Bankacılığı Kullanıp Kullanmaması) ile finansal okuryazarlık düzeyini ölçen sorular arasında anlamlı bir farkın olup olmadığ 1 belirlenmiştir. 
Tablo 1: Katılımcıların Demografik Özelliklerine Ait Bilgiler

\begin{tabular}{|c|c|c|c|}
\hline \multicolumn{2}{|l|}{ Demografik Özellikler } & Katılımcı Sayısı(N) & Yüzde(\%) \\
\hline \multirow{3}{*}{ Cinsiyet } & Kadın & $\begin{array}{r}181 \\
\end{array}$ & $43,61 \%$ \\
\hline & Erkek & 234 & $56,39 \%$ \\
\hline & TOPLAM & 415 & $100,00 \%$ \\
\hline \multirow{5}{*}{ Çalışma Alanları } & Sosyal Bilimler & 222 & $53,49 \%$ \\
\hline & Fen Bilimleri & 131 & $31,57 \%$ \\
\hline & Sağlık Bilimleri & 42 & $10,13 \%$ \\
\hline & Yabancı Diller & 20 & $4,81 \%$ \\
\hline & TOPLAM & 415 & $100,00 \%$ \\
\hline \multirow{6}{*}{ Yaş Aralığı } & $23-28$ & 73 & $17,59 \%$ \\
\hline & $29-34$ & 129 & $30,09 \%$ \\
\hline & $35-40$ & 117 & $\% 28.19$ \\
\hline & $41-46$ & 45 & $10,84 \%$ \\
\hline & 47 ve üstü & 51 & $12,29 \%$ \\
\hline & TOPLAM & 415 & $100,00 \%$ \\
\hline \multirow{3}{*}{ Eğitim Durumu } & Lisans & 33 & $7,92 \%$ \\
\hline & Lisans Üstü & 382 & $92,08 \%$ \\
\hline & TOPLAM & 415 & $100,00 \%$ \\
\hline \multirow{8}{*}{ Gelir Durumu } & $3000-3499$ & 80 & $19,28 \%$ \\
\hline & 3500-3999 & 49 & $11,80 \%$ \\
\hline & 4000-4499 & 65 & $15,66 \%$ \\
\hline & 4500-4999 & 68 & $16,39 \%$ \\
\hline & 5000-5499 & 75 & $18,07 \%$ \\
\hline & $5500-5999$ & 24 & $5,79 \%$ \\
\hline & 6000 ve üzeri & 54 & $13,01 \%$ \\
\hline & TOPLAM & 415 & $100,00 \%$ \\
\hline \multirow{4}{*}{ Akademik Unvanınız } & Arş. Gör. & 85 & $20,48 \%$ \\
\hline & Öğr. Gör. & 210 & $50,60 \%$ \\
\hline & Öğr. Üyesi & 120 & $28,92 \%$ \\
\hline & TOPLAM & 415 & $100,00 \%$ \\
\hline \multirow{3}{*}{ Bireysel Emeklilik Sistemine Dahil Misiniz? } & Evet & 221 & $53,25 \%$ \\
\hline & Hayır & 194 & $46,75 \%$ \\
\hline & TOPLAM & 415 & $100,00 \%$ \\
\hline \multirow{3}{*}{ Kredi kartınız var mı? } & Evet & 376 & $90,60 \%$ \\
\hline & Hayır & 39 & $9,40 \%$ \\
\hline & TOPLAM & 415 & $100,00 \%$ \\
\hline \multirow{3}{*}{ İnternet veya mobil bankacılık kullanıyor musunuz? } & Evet & 407 & $98,07 \%$ \\
\hline & Hayır & 8 & $1,93 \%$ \\
\hline & TOPLAM & 415 & $100,00 \%$ \\
\hline
\end{tabular}

Çalışmada erkekler 234 kişi ile yüzde 56,39'luk, kadınlar ise 181 kişi ile yüzde $43,6^{\prime}$ 'ık orana sahiptir. Çalışma alanına bakıldığında ankete katılan akademisyenlerin 53,49’u Sosyal Bilimler, yüzde 31,57'si Fen Bilimleri, yüzde 10'u Sağlık Bilimlerinde, yüzde 4,81'i Yabanc1 Diller bölümlerinde çalışmaktadır.

Ankete katılan akademisyenlerin yaşları incelendiğinde yüzde 75 'inin 40 yaşın altında olduğu tespit edilmiştir. Bu anlamda akademisyenlerin özellikle kredi kartı kullanımı, internet bankacılı̆̆ fazla bilgi sahibi olabileceği beklenmektedir.

Ankete katılan akademisyenlerin yüzde 92 'si lisansüstü mezunudur. 4500 liranın altında maaş alan akademisyen sayısı 194 kişi ile yüzde 46,74' lük; 4500 liranın üstünde maaş alan 221 kişi ile yüzde 53,25'lik orana sahiptir. 
Ankete katılan akademisyenlerin yüzde 53,25'i Bireysel Emeklilik Sistemine dahil olup yüzde 98,07'si İnternet veya Mobil Bankacilık kullanmakta ve yüzde 90,60'ının da Kredi Kartı bulunmaktadır. Bu sayılara bakıldığında akademisyenlerin çoğunun bireysel emeklilik ve bankacılık sistemlerini aktif bir şekilde kullandıkları görülmekte ve bu oranlar Türkiye ortalamasının üzerinde çıkmaktadır.

Tablo2: Finansal okur yazarlık puanı (Cinsiyet)

\begin{tabular}{|l|l|l|l|l|l|l|l|l|}
\hline \multirow{2}{*}{$\begin{array}{l}\text { Finansal okur } \\
\text { yazarlık puan }\end{array}$} & Cinsiyet & $\mathrm{N}$ & $\begin{array}{l}\text { Ortalam } \\
\text { a }\end{array}$ & $\begin{array}{l}\text { Std. } \\
\text { Spm }\end{array}$ & $\begin{array}{l}\text { Std. } \\
\text { Hata }\end{array}$ & $\mathrm{t}$ & df & $\begin{array}{l}\text { Sig. (2- } \\
\text { tailed) }\end{array}$ \\
\cline { 2 - 10 } & KADIN & 181 & 14,4144 & 3,41070 &, 25352 & $-9,633$ & 413 &, 000 \\
\cline { 2 - 10 } & ERKEK & 234 & 17,6325 & 3,34715 &, 21881 & \\
\hline
\end{tabular}

Cinsiyet ile finansal okuryazarlık düzeyleri arasında anlamlı bir fark olduğu tespit edilmiştir. Akademisyenlerin genel finansal okuryazarlık düzeyi 25 puan üzerinden 16,22 çıkmışır. Dünya genelinin paralelinde kadınların finansal okuryazarlık düzeyi erkeklerden daha düşük çıkmıştır. Kadınların genel finansal okuryazarlık düzeyi 14,41 iken erkeklerin okuryazarlık düzeyi ise 17,63 çıkmıştır.

Tablo 3: Finansal okur yazarlık puanı (Çalışma Alanları)

\begin{tabular}{|c|c|c|c|c|c|c|c|}
\hline Çalışma Alanı & $\mathbf{N}$ & Ortalama & $\begin{array}{l}\text { Std. } \\
\text { Spm }\end{array}$ & $\begin{array}{l}\text { Std. } \\
\text { Hata }\end{array}$ & df & $\mathbf{F}$ & Sig. \\
\hline Sosyal & 222 & 16,9054 & 3,63182 & ,24375 & \multirow{5}{*}{3} & \multirow{5}{*}{6,774} & \multirow{5}{*}{, 000} \\
\hline Fen & 131 & 15,8092 & 3,43089 & ,29976 & & & \\
\hline Sağllk & 42 & 14,7619 & 4,13675 & ,63831 & & & \\
\hline Yabanc1 Dil & 20 & 14,5500 & 4,24853 & 95000 & & & \\
\hline \multirow[t]{2}{*}{ Total } & 415 & 16,2289 & 3,73042 &, 18312 & & & \\
\hline & & & \multicolumn{2}{|c|}{ Ortalama Fark } & \multicolumn{2}{|c|}{ Std. Spm. } & Sig. \\
\hline \multirow[t]{3}{*}{ Sosyal } & \multicolumn{2}{|c|}{ Fen } & \multicolumn{2}{|l|}{1,09625} & \multicolumn{2}{|c|}{, 40265} &, 061 \\
\hline & \multirow{2}{*}{\multicolumn{2}{|c|}{$\begin{array}{l}\text { Sağlık } \\
\text { Yabancı Dil }\end{array}$}} & \multicolumn{2}{|l|}{$2,14350^{*}$} & \multicolumn{2}{|c|}{61498} &, 007 \\
\hline & & & \multicolumn{2}{|l|}{2,35541} & \multicolumn{2}{|c|}{85325} &, 056 \\
\hline
\end{tabular}

Ankete katılan akademisyenlerin çalışma alanları ile finansal okuryazarlık düzeyleri karşılaştırıldığında sadece Sosyal Bilimler ile Sağlık Bilimleri arasında anlamlı bir fark ortaya çıkmıştır. Bu fark Sağlı Bilimlerinde çalışan akademisyenlerin finansal okuryazarlık düzeylerinin düşük olmasından kaynaklanmaktadır.

Tablo 4: Finansal okur yazarlık puanı (Eğitim Durumu)

\begin{tabular}{|c|c|c|c|c|c|c|c|c|}
\hline \multirow{3}{*}{$\begin{array}{l}\text { Finansal } \\
\text { Okuryazarlık } \\
\text { Puanı }\end{array}$} & $\begin{array}{l}\text { Eğitim } \\
\text { Durumu }\end{array}$ & $\mathrm{N}$ & Ortalama & $\begin{array}{l}\text { Std. } \\
\text { Sapma }\end{array}$ & \begin{tabular}{|l|} 
Std. \\
Hata \\
\end{tabular} & $\mathrm{t}$ & df & $\begin{array}{l}\text { Sig. (2- } \\
\text { tailed) }\end{array}$ \\
\hline & Lisans & 33 & 14,9091 & 3,91602 & 68169 & \multirow{2}{*}{$-2,127$} & \multirow{2}{*}{413} & \multirow{2}{*}{,034 } \\
\hline & Lisansüstü & 382 & 16,3429 & 3,69723 & , 18917 & & & \\
\hline
\end{tabular}

Anket sonuçlarına göre eğitim durumu ile finansal okuryazarlık düzeyi arasında anlamlı bir fark tespit edilmiştir. Eğitim düzeyinin arttıkça finansal okuryazarlık düzeyinin de artmakta olduğu görülmektedir. 
Tablo 5: Finansal okur yazarlık puanı (Maaş)

\begin{tabular}{|c|c|c|c|c|c|c|c|c|}
\hline \multirow{9}{*}{$\begin{array}{l}\text { Finansal } \\
\text { okur } \\
\text { yazarlık } \\
\text { puanı }\end{array}$} & Maaş & $\mathbf{N}$ & Ortalama & $\begin{array}{l}\text { Std. } \\
\text { Spm }\end{array}$ & $\begin{array}{l}\text { Std. } \\
\text { Hata }\end{array}$ & df & $\mathbf{F}$ & Sig. \\
\hline & 3000-3499 TL & 14.9375 & 4,11648 & .46024 & 14.9375 & \multirow{8}{*}{6} & \multirow{8}{*}{3,458} & \multirow{8}{*}{,002 } \\
\hline & $3500-3999 \mathrm{TL}$ & 16,4490 & 3,16268 & ,45181 & 16,4490 & & & \\
\hline & $4000-4499$ TL & 16,2308 & 3,70291 & 45929 & 16,2308 & & & \\
\hline & $4500-4999 \mathrm{TL}$ & 15,7353 & 3,72013 & ,45113 & 15,7353 & & & \\
\hline & $5000-5499 \mathrm{TL}$ & 16,9200 & 3,61962 & ,41796 & 16,9200 & & & \\
\hline & $5500-5999 \mathrm{TL}$ & 16,4167 & 3,02046 & 61655 & 16,4167 & & & \\
\hline & 6000 TL ve üzeri & 17,5185 & 3,58056 & ,48725 & 17,5185 & & & \\
\hline & Toplam & 16,4490 & 3,16268 & 45181 & 16,4490 & & & \\
\hline \multirow{7}{*}{$\begin{array}{l}\text { 3000-3499 } \\
\text { TL }\end{array}$} & \multirow{7}{*}{$\begin{array}{l}3500-3999 \mathrm{TL} \\
4000-4499 \mathrm{TL} \\
4500-4999 \mathrm{TL} \\
5000-5499 \mathrm{TL} \\
5500-5999 \mathrm{TL} \\
6000 \mathrm{TL} \text { ve üzeri }\end{array}$} & $\begin{array}{l}\text { Ortalama } \\
\text { Fark }\end{array}$ & $\begin{array}{l}\text { Std. } \\
\text { Spm. }\end{array}$ & Sig. & & & & \\
\hline & & $-1,51148$ & ,66498 & 524 & & & & \\
\hline & & $-1,29327$ & ,61212 & ,615 & & & & \\
\hline & &,- 79779 & ,60463 & ,942 & & & & \\
\hline & & $-1,98250$ &, 58918 & 082 & & & & \\
\hline & & $-1,47917$ &, 85314 &, 808 & & & & \\
\hline & & $-2,58102^{*}$ & ,64560 & 015 & & & & \\
\hline
\end{tabular}

Akademisyenlerin geliri ile finansal okuryazarlık düzeyleri arasında karşılaştırma yapıldığında sadece 3500 TL'nin altında maaş alan akademisyenlerle 6000TL ve üzerinde maaş alan akademisyenlerin bilgi düzeyleri arasında anlamlı bir fark olduğu tespit edilmiştir. 6.000 TL'nin üzerinde maaş alan akademisyenlerin finansal okuryazarlık düzeyi 3.500 TL'nin altında maaş alan akademisyenden daha yüksek çıkmıştır. Bu çerçeveden bakıldığında belirli bir gelir düzeyine kadar finansal okuryazarlık düzeyinde anlamlı bir artış gözlenmezken bu gelir düzeyinin üzerinde elde edilen gelir finansal okuryazarlık düzeyini artırmıştır.

Tablo 6: Finansal okur yazarlık puanı (Akademik Unvan)

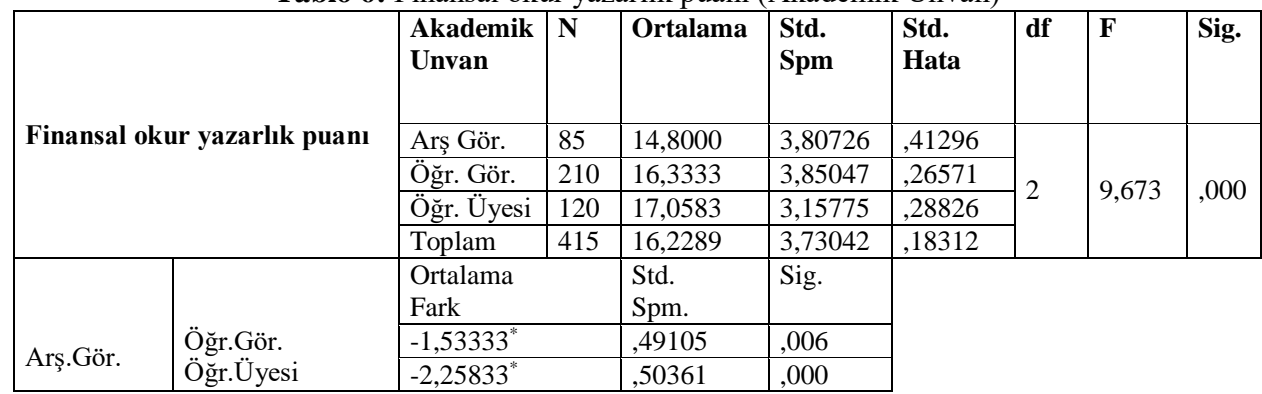

Akademik unvan ve finansal okuryazarlık düzeyi karşılaştırmasında sadece araştırma görevlisi ile öğretim görevlisi ve öğretim üyesi arasında anlamlı bir fark çıkmıştır. Araştırma görevlisinin finansal okuryazarlık düzeyi her iki unvandaki akademisyenlerden daha düşüktür. Öğretim görevlilerinin finansal okuryazarlık düzeyi öğretim üyelerinden düşük çıksa da bu fark istatistiki olarak anlamlı değildir. (Okutman, uzman olan akademisyenler 2547 ve 2914 sayıl1 kanunlardaki değişiklikle öğretim görevlisi kadrolarına geçirilmişlerdir.) 
Tablo 7: Finansal okur yazarlık puanı (Yaş)

\begin{tabular}{|c|c|c|c|c|c|c|c|c|}
\hline \multirow{7}{*}{$\begin{array}{l}\text { Finansal } \\
\text { Okuryazarlık } \\
\text { Puanı }\end{array}$} & Yaş & $\mathbf{N}$ & Ortalama & Std. Spm & Std. Hata & df & $\mathbf{F}$ & Sig. \\
\hline & $23-28$ & 73 & 14,3014 & 4,12204 & ,48245 & \multirow{6}{*}{4} & \multirow{6}{*}{10,237} & \multirow{6}{*}{,000 } \\
\hline & $29-34$ & 129 & 15,8140 & 3,56583 & ,31395 & & & \\
\hline & $35-40$ & 117 & 16,7009 & 3,41968 & ,31615 & & & \\
\hline & $41-46$ & 45 & 17,5111 & 3,05720 & 45574 & & & \\
\hline & 47 ve üzeri & 51 & 17,8235 & 3,51969 & ,49286 & & & \\
\hline & Total & 415 & 16,2289 & 3,73042 & ,18312 & & & \\
\hline \multirow{5}{*}{$23-28$} & & \multicolumn{2}{|c|}{ Ortalama Fark } & Std. Spm. & Sig. & & & \\
\hline & 29-34 & \multicolumn{2}{|c|}{,- 06050} & 02094 & 082 & & & \\
\hline & $35-40$ & \multicolumn{2}{|c|}{,$- 09598^{*}$} & 02132 & ,001 & & & \\
\hline & $41-46$ & \multicolumn{2}{|c|}{,$- 12839 *$} & 02710 &, 000 & & & \\
\hline & 47 ve üzeri & \multicolumn{2}{|c|}{,$- 14089 *$} &, 02609 &, 000 & & & \\
\hline
\end{tabular}

Anket sonuçlarına göre akademisyenlerin yaşları arttıkça finansal okuryazarlık düzeylerinde de istatistiki açıdan anlamlı bir artış olduğu gözlemlenmiştir. 23-28 yaş aralığındaki akademisyenlerin finansal okuryazarlık oranları diğer yaş aralıklarındaki akademisyenlere göre düşüktür. Yaş arttıkça finansal bilgi düzeyi de artmaktadır.

İnternet ve mobil bankacılık kullanıp kullanmama, bireysel emeklilik sistemine dahil olup olmama ile finansal okuryazarlık düzeyi karşılaştırıldığında istatistiki açıdan anlamlı bir sonuç elde edilememiştir.

\section{SONUÇ}

Finansal okuryazarlık düzeyi günümüzde kişilerin daha da karmaşık hale gelen finansal sistemde etkin rol almalarına yardımcı olmaktadır. Bireylerin tasarruf, harcama, yatırım ve kredi yönetimi konularında bilgi birikimlerinin artırılması gelecekte doğru finansal kararlar almalarını sağlayacaktır. Ayrıca finansal okuryazarlık düzeyinin artması çağımızın önemli problemlerinden biri olan finansal dolandırıcılıktan da korunma açısından yol gösterici olacaktır.

Finansal okuryazarlık düzeyi literatürdeki gibi temel ve gelişmiş olarak sınıflandırıldığında, bu ayırımın her ikisine de akademisyenlerin hâkim olması beklenmektedir. Çünkü ülkenin genel eğitim seviyesine bakıldığında ve akademisyenlerin çoğunun lisansüstü mezunu olduğu düşünüldüğünde, böyle bir beklentinin ortaya çıkması doğaldır. Ayrıca son yıllarda yapılan benzer çalışmalarda, eğitim düzeyi arttıkça finansal okuryazarlık düzeyinin de arttığı sonuçlarına ulaşılmaktadır. Finansal okuryazarlık düzeyi yüksek akademisyen, yaşamının her noktasında bu bilgisini kullanacağı için üniversitede yetiştirdiğ $i$ öğrencilerin de bu durumdan olumlu anlamda rol-model anlayışı içerisinde kendilerini geliştirecekleri düşünülmektedir. Bu açıdan bakıldığında dünyadaki trendin paralelinde gidebilmek açısından finansal okuryazarlık düzeyi yüksek bireyler yetiştirebilmek, öncelikle finansal okuryazarlık düzeyi yüksek eğitmenlerle, akademisyenlerle mümkündür.

Bu çalışma eğitim seviyesi ve gelir seviyesi ülke ortalamasının üzerinde olan akademisyenlerin, finansal okuryazarlık düzeylerini ölçmek amacıyla 
yapılmıştır. 415 akademisyenin katıldığ 1 anketler üzerine yapılan çalışmada, erkek akademisyenlerin dünya ortalamasına paralel olarak kadınlardan, Sosyal Bilimler alanında çalışan akademisyenlerin de diğer alanlarda çalışanlardan daha yüksek finansal okuryazarlık düzeyine sahip olduğu görülmüştür. Ayrıca akademisyenlerin eğitim seviyeleri arttıkça finansal okuryazarlık düzeylerinin de arttığı çalışmada elde edilen bir diğer sonuçtur.

Çalışmada gelir düzeyi arttıkça finansal okuryazarlık düzeyinin artıp artmayacağı üzerinde de durulmuş ve sadece $3.500 \mathrm{TL}$ ve altında maaş alan akademisyenlerle 6.000 TL ve üzerinde maaş alan akademisyenler arasında finansal okuryazarlık düzeyi açısından anlamlı bir fark olduğu ortaya çıkmıştır.

Akademik unvan olarak bakıldığında ise yalnızca araştırma görevlileri ile öğretim görevlileri ve öğretim üyeleri arasında anlamlı bir fark çıkmış, araştırma görevlilerinin daha düşük finansal okuryazarlık düzeyine sahip olduğu tespit edilmiştir.

Anket sonuçlarına göre akademisyenlerin yaşları arttıç̧a finansal okuryazarlık düzeylerinin de arttığı, en düşük finansal okuryazarlık düzeyine sahip yaş aralığının 23-28, en yükseğinin ise 47 yaş ve üzeri olduğu tespit edilmiştir.

Araştırmada elde edilen sonuçların hepsi beraber değerlendirildiğinde akademisyenlerin Türkiye ortalamasının üzerinde finansal okuryazar olduklarından söz edilebilir. Fen, sağlık ve yabancı dil alanlarında çalışan akademisyenlerin de finansal okuryazarlık düzeylerinin en az sosyal bilimler alanında çalışan akademisyenlerin seviyesine getirilmesi, hem akademisyenlerin gündelik yaşamlarına daha doğru yön vermeleri hem de yetiştirecekleri öğrencileri etkilemeleri açısından önemlidir. Sonraki çalışmalarda bu çalışmada bulunan tespitler ışığında akademisyenlerin finansal okuryazarlık düzeylerini artırmak için yol haritalarının çizilmesi ve bu konuyla ilgili projeler geliştirilmesinin faydalı olacağı düşünülmektedir.

\section{KAYNAKÇA}

Almenberg, J. \& Save-Söderberg J. (2011). Financial literacy and retirement planning in Sweden. CeRP Working Paper, No:112, Italy.

Altan, F. ve Biçer, E.B. (2016), Üniversite Öğrencilerinin Finansal Okuryazarlık ile İlgili Tutum ve Davranışlarının Değerlendirilmesi, Atatürk Üniversitesi Sosyal Bilimler Enstitüsü Dergisi, Aralık, 20(4), ss. 1501-1517.

Amagir, Aisa \& Groot, Wim \& Maassenvandenbrink, H \& Wilschut, A. (2017). A review of financial-literacy education programs for children and adolescents. Citizenship, Social and Economic education. 2017

Barış, S. (2016). Finansal Okuryazarlık ve Bütçeleme Davranışı: Üniversite Öğrencileri Üzerine Bir Araştırma. TESAM Akademi Dergisi, 3(2), 13-38.

Danışman ,Sezer D Ve Gümüş U.T, Finansal Okuryazarlık Düzeyinin Belirlenmesi: Üniversite Öğrencileri Üzerine Bir Araştırma, Kara Harp Okulu Bilim Dergisi,12,2016

Dick, J. (2013). Knowing what not to do: financial literacy and consumer credit choices, Master Thesis: 6-14.

Er B., Şahin Y.E., Mutlu M., "Finansal Eylem ve Finansal Okuryazarlık: Üniversite Öğrencilerine Yönelik Bir Araştırma", Finans Politik \& Ekonomik Yorumlar, vol.54, pp.75-88, 2017

FINLIT "Financial Literacy around the World (2015)" https://responsiblefinanceforum.org/wpcontent/uploads/2015/12/2015-Finlit_paper_17_F3_SINGLES.pdf Erişim(22.04.2018) 
Gosaitse E. Solomon \& Trust Nhete \& Burman M. Sithole.(2018) The Case for the Need for Personal Financial Literacy Education in Botswana Secondary Schools , SAGE Open, 8(1), (2018).

Gutnu, M.M. ve Cihangir M. (2015). Finansal Okuryazarlık: Osmaniye Korkut Ata Üniversitesi Personeli Üzerinde Bir Araştırma. Akademik Sosyal Araştırmalar Dergisi, 3(10), 415-424.

Huston, S. J. (2010). Measuring Financial Literacy, Journal of Consumer Affairs, 44(2). ss. 296316.

Jappelli, T. \& Padula, M., (2011). Investment in financial literacy and saving decisions. CSEF Working Paper, No. 272, University of Naples, Italy.

Kılıç, Y.,Ata, H.A. ve Seyrek, İ. H. (2015). Finansal Okuryazarlık: Üniversite Öğrencilerine Yönelik Bir Araştırma. Muhasebe ve Finansman Dergisi, 17(66), 129-150.

Lusardi, A., Mitchell, O. S. ve Curto, V. (2010). Financial Literacy Among the Young. Journal of Consumer Affairs, 44(2). ss. 358-380.

Lusardi, A. \& Mitchell, O. S. (2014). The economic importance of financial literacy: theory and evidence. Forthcoming Journal of Economic Literature 52(1),5 - 44.

Mahdzan, N. E. ve Tabiani, S. (2013). The Impact of Financial Literacy on Individual Saving: an Exploratory Study in the Malaysian Context. Transformations in Business \&Economics, 12(1). ss. 41-55.

Ricci, O. and Caratelli, M. (2017) Financial literacy, trust and retirement planning. Journal of Pension Economics and Finance, 16: 43-64.

Şamiloğlu, F., Y. E. Kahraman, H. Bağc1 (2016) "Finansal Okuryazarlık Araştırması: Erciyes Üniversitesi Öğrencileri Üzerinde Bir Uygulama”, Uluslararası Yönetim Íktisat Ve İşletme Dergisi (Icafr 16 Özel Sayıs1).

Yıldırım, M., Bayram, F., Oğuz, A., \& Günay, G. (2017). Financial Literacy Level of Individuals and Its Relationships to Demographic Variables. Mediterranean Journal of Social Sciences, 8(3), 19.

\section{EKLER}

EK Tablo 1: Yatırım Bilgisini İnceleyen Sorular

\begin{tabular}{|l|c|c|}
\hline Sorular & \multicolumn{2}{|c|}{ n=415 } \\
\cline { 2 - 3 } & Doğru Cevap (\%) & Yanlış Cevap (\%) \\
\hline $\begin{array}{l}\text { Enflasyon oranının \%15 olduğu bir ülkede yıllık \%12 den } \\
\text { konut kredisi çekip kredi almak doğru bir yatırımdır. }\end{array}$ & 41,22 & 58,78 \\
\hline $\begin{array}{l}\text { Tasarruf kişinin ihtiyaçlarını karşıladıktan sonra kalan kısmı } \\
\text { biriktirmesidir. }\end{array}$ & 84.88 & \\
\hline $\begin{array}{l}\text { Bir kişinin bir malı peşin olarak alması ile vade farksız 5 taksit } \\
\text { alması arasında getiri açısından hiçbir fark yoktur. }\end{array}$ & 53,17 & \multicolumn{2}{|c|}{46,83} \\
\hline Aracı kurumlar olmadan hisse senedi satın alınamaz. & 25,61 & 74,39 \\
\hline Döviz,hisse senedi ve gayrimenkul yatırım araçlarıdır. & 91,46 & 8,55 \\
\hline Hisse senedi almak çok riskli bir yatırımdır. & 53,90 & \\
\hline
\end{tabular}


EK Tablo 2: Türkiye Ekonomisini İnceleyen Sorular

\begin{tabular}{|l|c|c|}
\hline Sorular & \multicolumn{2}{|c|}{ n=415 } \\
\cline { 2 - 3 } & Doğru Cevap (\%) & Yanlış Cevap (\%) \\
\hline Türkiyede enflasyon 2002 yılından beri \%10'un altına düşmemiştir. & 61,46 & 38,54 \\
\hline $\begin{array}{l}\text { Türkiye'de işsizlik oranları 2002 yılından beri \%15'in altına } \\
\text { düşmemiştir. }\end{array}$ & 52.44 & 47,56 \\
\hline $\begin{array}{l}\text { Dövizin Türk Lirası karşısındaki değerinin artması ithalatçı için } \\
\text { olumlu bir durumdur. }\end{array}$ & 72,20 & \\
\hline
\end{tabular}

EK Tablo 3: Bankacılık Sistemini İnceleyen Sorular

\begin{tabular}{|c|c|c|}
\hline \multirow[t]{2}{*}{ Sorular } & \multicolumn{2}{|c|}{$n=415$} \\
\hline & Doğru Cevap (\%) & Yanlış Cevap (\%) \\
\hline $\begin{array}{l}\text { Yurtdışına para göndermek için kişinin ya da şirketin IBAN } \\
\text { numarasını bilmek gerekir. }\end{array}$ & 57,80 & 42,20 \\
\hline Kısa vadeli kredi almak daha az faiz ödememizi sağlar. & 83,66 & 16,34 \\
\hline $\begin{array}{l}\text { Tüm bankaların mevduat faiz oranları ve kredi faiz oranları } \\
\text { aynıdır. }\end{array}$ & 94,88 & 5,12 \\
\hline Havale başka banka hesabına para gönderme işlemidir. & 73,90 & 26,10 \\
\hline Vadesiz türk lirası hesabına para yatırarak gelir elde edilebilir. & 84,63 & 15,37 \\
\hline $\begin{array}{l}\text { Konut kredisi faiz oranı bireysel kredi faiz oranından daha } \\
\text { yüksektir. }\end{array}$ & 69,27 & 30,73 \\
\hline $\begin{array}{l}\text { Aynı orana sahip bireysel kredi ve taşıt kredisinden bireysel } \\
\text { krediyi tercih ederim. }\end{array}$ & 57,32 & 42,68 \\
\hline $\begin{array}{l}\text { İnternet üzerinden tüm sitelerden alışveriş yaptığınızda kredi kartı } \\
\text { bilgilerinizin başkalarının eline geçerek sizden habersiz alışveriş } \\
\text { yapılır. }\end{array}$ & 57,56 & 42,44 \\
\hline İnternet sitesinin güvenli olduğunu gösteren bir simge vardır. & 76,83 & 23,17 \\
\hline
\end{tabular}

EK Tablo 4: Bireysel Emekliliği ve SGK'dan Emekliliği İnceleyen Sorular

\begin{tabular}{|l|c|c|}
\hline Sorular & \multicolumn{2}{|c|}{ n=415 } \\
\cline { 2 - 3 } & Doğru Cevap (\%) & Yanlıs Cevap (\%) \\
\hline $\begin{array}{l}\text { Bireysel emeklilikte \%25 devlet katkısından başka getiri elde } \\
\text { edilemez. }\end{array}$ & 64,39 & 35,61 \\
\hline $\begin{array}{l}\text { SGK'dan emekli olurken kadın ve erkeğin emeklilik yaşında bir fark } \\
\text { yoktur. }\end{array}$ & 89,27 & 10,73 \\
\hline $\begin{array}{l}\text { Bireysel emeklilik sisteminden emekli olabilmek için 56 yaşını } \\
\text { beklemek gerekir. }\end{array}$ & 37,56 & 62,44 \\
\hline
\end{tabular}


EK Tablo 5: Araç Sigorta- Kaskosu Ve Türk Vergi Sistemini İnceleyen Sorular

\begin{tabular}{|l|c|c|}
\hline Sorular & \multicolumn{2}{|c|}{ n=415 } \\
\cline { 2 - 3 } & Doğru Cevap (\%) & Yanlış Cevap (\%) \\
\hline $\begin{array}{l}\text { İlk defa araç sahibi olan kişi ile 10 yıllık aracı olan kişinin } \\
\text { zorunlu trafik sigorta primleri aynıdır. }\end{array}$ & 82,20 & 17,80 \\
\hline $\begin{array}{l}\text { Tüm araçlara hem zorunlu trafik sigortası hem de kasko yapılmak } \\
\text { zorundadır. }\end{array}$ & 82,93 & 16,07 \\
\hline $\begin{array}{l}\text { Gerçek kişi ne kadar gelir elde ederse etsin \%15 gelir vergisi } \\
\text { öder. }\end{array}$ & 52,20 & 47,80 \\
\hline $\begin{array}{l}\text { Kurumlar vergisine tabi olan bir şirket ne kâr elde ederse etsin } \\
\text { yıllık kârının \%22'si oranında kurumlar vergisi verir. }\end{array}$ & 21,71 & 78,29 \\
\hline
\end{tabular}

EK Tablo 6: Kadınların Genel Olarak Yanlış Cevap Verdiği Sorular

\begin{tabular}{|c|c|c|}
\hline \multirow[t]{2}{*}{ Sorular } & \multicolumn{2}{|c|}{$\mathrm{n}=\mathbf{1 8 1}$} \\
\hline & Doğru Cevap (\%) & Yanlış Cevap (\%) \\
\hline $\begin{array}{l}\text { Enflasyon oranının \%15 olduğu bir ülkede yıllık } \% 12 \text { den } \\
\text { konut kredisi çekip kredi almak doğru bir yatırımdır }\end{array}$ & 23,20 & 76,8 \\
\hline $\begin{array}{l}\text { Türkiye'de işsizlik oranları } 2002 \text { yılından beri \%15'in altına } \\
\text { düşmemiştir }\end{array}$ & 28,20 & 71,8 \\
\hline Hisse senedi almak çok riskli bir yatırımdır & 43,10 & 56,9 \\
\hline $\begin{array}{l}\text { Kurumlar vergisine tabi olan bir şirket ne kâr elde ederse etsin } \\
\text { yılllık kârının \%22'si oranında kurumlar vergisi verir }\end{array}$ & 16 & 84 \\
\hline $\begin{array}{l}\text { Bireysel emeklilik sisteminden emekli olabilmek için } 56 \text { yaşını } \\
\text { beklemek gerekir }\end{array}$ & 34,30 & 65,7 \\
\hline $\begin{array}{l}\text { Türkiye'de enflasyon } 2002 \text { yılından beri \%10'un altına } \\
\text { düşmemiştir }\end{array}$ & 40,90 & 59,1 \\
\hline Aracı kurumlar olmadan hisse senedi satın alınamaz. & 16 & 84 \\
\hline $\begin{array}{l}\text { Gerçek kişi ne kadar gelir elde ederse etsin \%15 gelir vergisi } \\
\text { öder }\end{array}$ & 42 & 58 \\
\hline $\begin{array}{l}\text { Bir kişinin bir malı peşin olarak alması ile vade farksız } 5 \text { taksit } \\
\text { alması arasında getiri açısından hiçbir fark yoktur }\end{array}$ & 46,40 & 53,6 \\
\hline
\end{tabular}

EK Tablo 7: Erkeklerin Genel Olarak Yanlış Cevap Verdiği Sorular

\begin{tabular}{|l|c|c|}
\hline Sorular & $\mathbf{n = 2 3 4}$ & Yanlış Cevap (\%) \\
\cline { 2 - 3 } & Doğru Cevap (\%) & 67 \\
\hline Aracı kurumlar olmadan hisse senedi satın alınamaz. & 33 & 6 \\
\hline $\begin{array}{l}\text { Bireysel emeklilik sisteminden emekli olabilmek için 56 yaşını } \\
\text { beklemek gerekir. }\end{array}$ & 40 & 73,9 \\
\hline $\begin{array}{l}\text { Kurumlar vergisine tabi olan bir şirket ne kâr elde ederse etsin } \\
\text { yıllık kârının \%22'si oranında kurumlar vergisi verir. }\end{array}$ & 26,1 & \\
\hline
\end{tabular}




\section{SUMMARY}

Financial literacy is the level of competence that helps make decisions that are rational and cost-effective, in order to use the money of the individual correctly. In other words, it is the competency that enables the individual to establish the budget balance. In order to prevent waste of resources and to form savings awareness, it is essential to train highly qualified people. At the same time it is a topic that needs to be emphasized so much. Financial literacy, however, is a comprehensive concept covering economics, banking and finance, saving knowledge, the tax system, the pension and the insurance system.

Individuals with high levels of financial literacy will create funds for the actions they want to achieve in the future by establishing well-balanced spending and savings. Increasing saving rates of households will reduce the need for countries to find foreign funding which is more costly and risky for them. Thus, countries will be able to provide the budget balance more easily. This awareness, which will be initiated by household members, will cause significant differences in governments' policies with the butterfly effect.

There are numerous studies in the literature on financial literacy that have been applied to different professions and working groups. However, very little research has been done on academicians who are at the top of the education level of the country and therefore expected to have the highest level of financial literacy. Significance levels of demographic factors and financial information levels were tested by ANOVA $\mathrm{T}$ test. A total of 25 questions were asked to measure the financial knowledge of academics These 25 questions made up of investment information, information related to Turkey's economy, the banking and financial system, Social Security and pension system, vehicle insurance and the insurance, Turkish tax system.

Usually men to questions about Turkey's economy is seen that the right answer than women. In addition, women responded incorrectly to questions investigating the Turkish tax system and investment knowledge.

In 2015, FINLIT has worked on more than 150,000 people in the world. The purpose of this study is to measure the financial literacy level of adults. Financial literacy level of adults in Turkey is $24 \%$. This ratio is well below the average when compared to developed countries. Therefore, measuring and increasing the financial literacy levels of academicians will also contribute to the students who will be trained. In this way, the level of financial literacy that is under developed and developing countries can be increased. 